This is the version of the article accepted for publication in Review of Political Economy published by Taylor and Francis: https://doi.org/10.1080/09538259.2018.1496549

Accepted version downloaded from SOAS Research Online: http://eprints.soas.ac.uk/26112

\title{
MARX, FINANCE AND POLITICAL ECONOMY
}

\author{
Jan Toporowski
}

\author{
Economics Department, SOAS University of London, Thornhaugh Street, London \\ WC1H 0XG, UK, email: jt29@soas.ac.uk
}

\begin{abstract}
Shortly after the publication of Volume 1 of Capital, the financial requirements of capitalist enterprise forced the financial innovation of bond and stock finance for joint stock companies. Marx intended to re-write Capital in order to incorporate this change. He did not achieve this. The economic analysis of capitalism with long-term finance was undertaken by Hilferding in his Finance Capital. Thereafter, a strand of economic analysis emerged in the work of Austro-Marxists, Veblen, Keynes, Kalecki, Steindl, Sweezy and the Italian Kaleckians Joseph Halevi and Riccardo Bellofiore, that incorporated into their analysis of production as well as distribution the change made to the structure and dynamics of capitalism by longterm finance. However, this shift in capitalist financing has largely been ignored in economic theory, while much of the heterodox analysis that seeks to challenge the role of finance in contemporary capitalism has not integrated finance consistently. The change from the classic capitalism to finance capital raises important questions about the meaning and relevance of Marx's work today.
\end{abstract}

Key words: Marx, Hilferding, corporate finance, credit.

JEL Classification: B14, B24, E44, P12

\section{Introduction}

To understand Marx (or any other great thinker) truly it is necessary to understand not only what he wrote, but also the structure of what he wrote. Only in the context of that structure is it possible to find out the meaning of particular observations. In other words, it is necessary to understand what was Marx's project and, in this essay, how that project was continued by his followers into the twentieth century. Marx's project was to uncover how capitalist production 
and distribution determine the way in which capitalism has evolved, combined with a systematic criticism of economic ideas and policy. For Marx, this deconstruction of capitalism was necessary because, unlike in previous modes of production, the process of producing a surplus, that is the process of exploitation of human labour, is not obvious in a capitalist economy. It is hidden by market processes that masquerade as 'free exchange' of commodities, or what Marx called 'The Mystery of the Fetishistic Character of Commodities' (Marx 1938, chap. 1, sect. 4. See also the Preface, and the Preface to Marx 1970).

The realisation of capitalist surplus was described by Marx in Volume II of Capital, subtitled The Process of the Circulation of Capital. This process is what we now call the circular flow of income: the income flows that Marx described in the schemes of reproduction laid out in this volume. However, he was not satisfied with the draft he had written and intended to revise it. In particular, he showed in the volume a scheme of simple reproduction (reproduction without any increase in production, or of the capital stock), but he did not complete the exposition of expanded reproduction (Marx 1974a, chaps XX, XXI). That 'process of the circulation of capital' is the origin of critical political economy in the twentieth century, in the theories of Kalecki, Goodwin and Sraffa.

In the paper that follows it is argued that financial innovation in the latter half of the nineteenth century changed fundamentally the corporate finance of capitalism. This affected not only the real circulation of capital, what may be called the 'industrial circulation' of capital. The innovations added to it a complex system of 'financial circulation' of money and capital (cf. Keynes [1930] 1971, ch. 15). The result was to change not only the circulation of money and capital in the modern economy, but also to alter the structures of capitalist economies, the key financial parameters in those economies, and the dynamics of those 
economies. The section that follows examines the rise of long-term finance; section 2 outlines the resulting changes in the business cycles or dynamics of the capitalist economy; sections 3 and 4 summarise briefly how political economy has responded to the change in the way in which capitalism functions. A conclusion then looks at how we may understand the work of Marx in the light of the change in corporate finance.

\section{The rise of long-term finance}

Following the writing of Capital, a radical change occurred in the financing of the capitalist economy, in the form of the emergence and proliferation of markets for long-term debt and shares in capitalist enterprises. Legislation from the 1860s onwards eased the establishment of joint stock companies in the advanced capitalist countries, pioneered in particular in Britain and the United States. This transformed capitalism from its 'classic' form in the midnineteenth century, in which capitalist enterprises were owned and controlled by individual capitalists and their more or less active partners, into its modern, twentieth-century form dominated by large joint-stock companies (see Kindleberger 1993, ch. 11) ${ }^{1}$. Earlier jointstock companies to build canals and railways, and to finance coal mines, had required special legislation to set them up. Marx noted these changes in his notebooks, but did not write down any more systematic account of the significance of the changes (Dellheim 2018).

The more general availability of long-term finance set off processes of centralisation of control of capital, and concentration of capitalist production in much larger scale capacity, and this effect is commonly recognised among Marxists. However, two consequences of radical importance for the stability of capitalism were less recognized.

\footnotetext{
1 Engels tried to incorporate this shift into Marx's Capital with a short chapter on the Stock Market that he added to Volume III of Capital (Marx 1974b). But Engels did not go beyond deprecating the speculation in that market, in terms that are common currency in modern, superficial critiques of finance (see Dellheim 2018).
} 
First, large capitalist enterprises with access to capital (long-term debt and equity) markets were able to 'fund' their long-term industrial assets with bonds, or equity. This reduced their vulnerability to credit shortages. Before this change in financing, the 'classic' capitalist enterprise was typically financed with the owner's capital. As mechanisation of production proceeded, there was an incessant need for additional capital, that was usually met by shortterm bank borrowing which had to be rolled over during the life-time of the productive capital equipment that it was financing (see Dobb 1967, pp. 26-30; Niebyl 1946, ch. 3; Kindleberger 1993, pp. 94-6). If banks became reluctant to lend, the capitalist entrepreneur (Marx's 'functioning', or 'actual' capitalist) would be unable to roll over outstanding shortterm debt and, faced with a squeeze on his liquidity, his company could fail. This is the financial crisis that is typical of 'classic' capitalism, when an investment boom would give rise to a more rapid circulation of money outside the banking system, particularly when wages were paid in coin. With a note issue restricted to gold reserves, the running down of paper money, coins and gold in bank reserves would cause banks to raise interest rates, to discourage borrowing. When that failed to reduce the demand for credit, banks would refuse to roll over credit. These banking crises were described in the text that formed the basis of the theory of financial crisis in both mainstream economics, and radical political economy, Tugan-Baranovsky's study of English banking crises, which accompanied his famous 'solution' to the problem of the declining rate of profit by means of increasing the capitalintensity of production (Tugan-Baranovsky 1923).

Banking crises of 'classic capitalism' were typically associated by critical observers with 'under-consumption', the idea that deficient demand arose from a lack of consumption. In his 1932 preface to the second edition of Hyndman's Commercial Crises, which drew on Tugan- 
Baranovsky's study, the great liberal political economist John A. Hobson, who was to influence Lenin's theory of imperialism, attributed the characteristics of nineteenth century crises to the crises of the twentieth century, with clear underconsumptionist implications:

The interest of modern readers will be attracted by the common character of the nine crises of last century, and by the flood of light they throw upon the present troubles of the world. Even in the slump which followed the Napoleonic war the germ of all the later slumps was plainly discernable, the glut of commodities unsaleable by reason of the fall of prices, the stoppage of production throughout the industrial system, and the lingering waste of unemployment. In each succeeding crisis, though financial troubles figured as the immediate cause of collapse, the same paradox which confronts the world to-day was plainly visible, an acceleration of the power of production unaccompanied by a corresponding growth of purchasing and consuming power.' (Hobson 1932, p. vii).

Second, the change in capitalist financing affected not only the organisational forms and structure of capitalist enterprise. It also changed the course of financial crisis, and capitalist dynamics in general. The emergence of long-term debt markets allowed the capitalist entrepreneur to refinance his short-term bank borrowing with long-term bonds. For the capitalist with access to such long-term finance, such finance virtually eliminated the vulnerability of to a bank credit squeeze (cf. Hilferding [1910] 1981, pp. 87-8). At the same time, the capitalist entrepreneur had to ensure that his company now had sufficient liquid reserves to make interest and dividend payments on long-term debts, or equity, and then to make sure that the holders of the bonds or shares were not embarrassed by the drying up of liquidity in the markets for bonds or shares: such a drying up makes it difficult to sell a bond or share for a good price and condemns its owner to holding it until prices improve, with only a cash flow in the form of interest or dividends. Hence companies are obliged to hold excess capital that is turned over in restructuring their financing. 


\section{The new business cycle}

The second major change attendant upon the expansion of long-term finance was the rise of monopoly capital. Companies could now expand far more expeditiously by buying their competitors' long-term debts or shares, rather than entering into the precarious business of competing their competitors out of business. The trusts and monopolies that dominated capitalism by the end of the nineteenth century were the creation of the capital markets, rather than, as academics like Alfred Marshall believed, the results of either 'natural', or political monopolies or increasing returns to scale. Rudolf Hilferding recognised that the link with the capital markets (rather than the link, between German big business and the Berlin clearing banks, for which he is best remembered) forms the essence of monopoly capital. In Finance Capital, Hilferding first put forward an explanation of a new kind of capitalist instability that now arose, caused by the interplay between monopoly and competitive segments in the capitalist economy: Corporations can stabilise their finances through access to the capital market and the use of monopoly power and cartels to secure a disproportionately large share of the surplus generated in the economy. This meant that they were less inclined, in a recession, to eliminate the excess capacity whose scrapping was the precondition for an investment-led recovery. This prolongs economic depression, and forces the burden of adjustment in productive capacity onto the competitive sector of the economy (Hilferding [1910] 1981, ch. 20). Hilferding anticipated that capitalists in the competitive sector of the economy would naturally get fed up with having economic crises dumped on them by monopolists and would eventually join cartels to secure some protection from economic instability, as the prelude to the establishment of an economy-wide 'general cartel' (Hilferding [1910] 1981, pp. 233-4). 
Traditional Marxism had been based on Marx's observations of 'classic' capitalism, since the three volumes of Capital, including volume 1, the only volume published by Marx, and the accompanying three volumes of Theories of Surplus Value, had all been written before 1867. Hilferding and his Austro-Marxist followers such as Otto Bauer and Emil Lederer, also rejected the labour theory of value as a theory of prices. Hilferding had defended Marx's labour theory in the face of earlier criticism from Eugen von Böhm-Bawerk, who favoured Karl Menger's of the subjectivist approach to value. In his Finance Capital, Hilferding added one further reason why the labour theory of value could not be the basis of a theory of actual prices: the transformation of labour values into prices requires the application of a common rate of profit across all activities, in particular in order to value the 'dead' labour embodied in the industrial equipment used in capitalist production. Marx had argued that this common rate of profit emerges through the competition of capitals to secure the highest possible profit (Marx 1974b, ch. X). However, this necessary step in the transformation of labour values into prices is compromised if there is not a common rate of profit, but various firms have different rates of profit according to their market power and their access to finance.

For Hilferding the consequence of this for the labour theory of value, as a theory of prices, is devastating: 'It seems that the monopolistic combine [i.e., cartel], while it confirms Marx's theory of concentration, at the same time tends to undermine his theory of value.' (Hilferding [1910] 1981, p. 228). Ultimately, with the spread of cartelisation and monopolies, prices are reduced to accounting devices, mere book-keeping parameters determining transfers between members of a 'general cartel' supported a 'central bank' 'and, from their combination emerges the enormous concentrated power of finance capital' (Hilferding [1910] 1981, p. 234). 
Hilferding's conclusion that capitalism had now changed its mode of operation, its structure and its dynamics, was widely accepted by Marxists, even if many rejected his view that cartelisation and the coordination of business activity could effectively stabilise the capitalist economy ${ }^{2}$. From the theoretical legacy of Hilferding, his theory of imperialism, and his distinction between 'classic' and 'monopoly' capitalism, were broadly accepted by Marxists such as Vladimir Lenin ([1915] 1969. Cf. Niebyl 1946, pp. 1-2). The greatest controversy among Marxists was aroused by Hilferding's hints that capitalism can be stabilised by the management of its markets. Among the Marxists of central Europe, the arguments around this overlapped with the arguments over Rosa Luxemburg's critique of Marxist orthodoxy, and the questions she raised about how surplus value is turned into money. On the one hand, Tugan-Baranovsky had sketched possibilities of capitalist development with greater use of machinery, possibilities limited, as in Hilferding, by political contradictions. On the other hand, Henryk Grossman argued that capitalism is destined to collapse due to the inevitability of the decline in surplus (see Kowalik [1971] 2014, Appendix II).

Among the contributors was the German social democrat Emil Lederer who, in 1927, published a theory of the business cycle that can be seen as a direct criticism of Hilferding's economic stabilisation thesis. Lederer (1925) argued that monopolies and cartels tend to make business cycles more extreme because those monopolies will tend to over-invest in a boom, and ensure that consumer prices will not fall in a recession by as much as wages (so that real wages will fall). He therefore attributed booms to investment but, regarded recessions and depressions as being ultimately caused by a lack of consumption demand.

\footnotetext{
${ }^{2}$ To give him his due, Hilferding did not mean that capitalism could eliminate its problems and contradictions. But these would be more political and social rather than economic. Class antagonisms would remain and of course the whole system was becoming dependent on imperialism (Hilferding [1910] 1981, chaps 22, 23).
} 
The impact of the changes wrought on capitalist structure and activity by the transformation of corporate finance is summarised in Table 1. Long-term finance allowed the emergence of large corporations that proceeded to dominate the markets even where the majority of capitalist enterprises remained solely owned, or partnerships. Formally those corporations retained the structure of older joint stock companies, pre-dating the mid-nineteenth century. But those earlier companies had largely been set up to provide finance for commerce or infrastructure, rather than industrial production (with the exception of mining in the eighteenth century).

With the shift of financing from the owner--capitalists personal savings and bank credit, the long-term rate of interest emerges as the key financial market parameter. Intriguingly, this had already been noted by Marx, but as an immanent possibility, rather than as an actual price of finance. Marx (1974b, pp. 362, 366) referred to it as 'the rate of interest for investments that require long-term loans of capital' and he thought that it was rather stable (as was later to be rediscovered when economists got down to investigating Keynes's propositions about the long-term rate of interest) (Toporowski 2018). In classic capitalism, the bank rate of interest fluctuated with the monetary business cycle, although Marx (1993) clearly rejected the notion that the business cycle was a monetary phenomenon. However, once long-term finance became available, corporations were able to 'hedge' their long-term productive assets with matched financing, making those corporations independent of bank liquidity and credit policy. With the development of credit and central banking, reserve drains from banks, which feature so much in Marx's accounts of capitalist crises, ceased to be a problem (until 2007, when central banks forgot their responsibility to maintain the liquidity of commercial banking). As triggers of financial crises, bank reserve drains were replaced by illiquidity in the secondary 
market for long-term securities, starting with the 1873 Vienna Stock Market Crash, and culminating in the 1929 Crash and, most recently, the 2008 crisis in the United States.

TABLE 1: 'Classic' and 'Monopoly Finance' Capitalism: A Comparison

\begin{tabular}{|c|c|c|}
\hline & 'Classic' Capitalism & $\begin{array}{l}\text { Monopoly Finance } \\
\text { Capitalism }\end{array}$ \\
\hline 1. Agency & Individual capitalist & $\begin{array}{l}\text { Joint stock companies \& } \\
\text { individual capitalists in } \\
\text { smaller enterprises }\end{array}$ \\
\hline 2. Finance & $\begin{array}{l}\text { Personal savings + bank } \\
\text { borrowing }\end{array}$ & $\begin{array}{l}\text { Long-term finance (for } \\
\text { corporates) }\end{array}$ \\
\hline $\begin{array}{l}\text { 3. Joint stock company } \\
\text { activity }\end{array}$ & $\begin{array}{l}\text { Merchant trade and } \\
\text { infrastructure }\end{array}$ & Industrial production \\
\hline 4. Key interest rate & Bank (short-term) rate & Long-term rate of interest \\
\hline $\begin{array}{l}\text { 5. Business cycle } \\
\text { mechanism }\end{array}$ & Monetary business cycle & Investment cycle \\
\hline 6. Crisis mechanism & Bank reserve drain & Capital market crash \\
\hline $\begin{array}{l}\text { 7. Dominant political } \\
\text { class }\end{array}$ & $\begin{array}{l}\text { Pre-capitalist ruling class or } \\
\text { merchant capitalists. }\end{array}$ & $\begin{array}{l}\text { Industrial and finance } \\
\text { capitalists. }\end{array}$ \\
\hline
\end{tabular}

\section{Finance's Impact on Political Economy}

In regard to the boom, Lederer was clearly anticipating Kalecki. Kalecki later observed that his theory was already "contained in the famous Marxian scheme of "extended reproduction"”. But, in Volume II of Capital the problems of the business cycle 
are treated by Marx from a rather special point of view. He is interested in finding out, with the help of exchange equations, the pace of investment in investment and consumption goods industries, which is necessary in order to secure a steady expansion of output... He does not pay attention to the problem of what happens if investment is inadequate to secure the moving equilibrium, and therefore does not approach the idea of the key position of investment in the determination of the level of total output and employment. Exactly the reverse attitude is represented by one of his eminent pupils, Rosa Luxemburg. In her Akkumulation des Kapitals she stressed the point that, if capitalists are saving, their profits can be "realized" only if a corresponding amount is spent by them on investment. She, however, considered impossible the persistence of net investment. ... The theory cannot be accepted as a whole, but the necessity of covering the "gap of saving" by home investment or exports was outlined by her perhaps more clearly than anywhere else before the publication of Mr. Keynes's General Theory. (Kalecki 1939, pp. 45-6)

Kalecki thought that he was resolving the theoretical problems left over from Marx and Luxemburg. But in truth Kalecki's business cycle theory is a response to Hilferding's monopoly stabilisation thesis. This is most explicit in Kalecki's early paper 'The Influence of Cartelization on the Business Cycle' where he argued, like Lederer before him, that cartels and monopolies, far from moderating the business cycle, make it more extreme. In booms, firms tend to over-invest to increase their production 'quotas', while their ability to secure excess profits in recessions makes cartelised firms reluctant to eliminate excess capacity. That excess capacity then discourages the resumption of investment. Dismissing the notion that price flexibility could secure equilibrium, he observed that 'in a partially cartelized system, cyclical fluctuations of output will be greater than in a system of completely free competition. In particular, cartels intensify the course of the crisis - not primarily because they have "rigid" prices, but because greater profits during this period are not followed by correspondingly greater investment activity' (Kalecki [1932] 1990). 
Kalecki and subsequently his friend Josef Steindl thus took on Marx's project and developed it for the conditions of twentieth century capitalism, building on the work of Luxemburg and Hilferding, to become founders of Post-Keynesian Economics. Kalecki's and Steindl's work is the clearest exposition of Marx's influence on Post-Keynesianism after Joan Robinson's (1942) Essay on Marxian Economics.

However, the main inspiration of Post-Keynesian economics came from the work of John Maynard Keynes, who presented a different, Marshallian narrative on finance. Keynes made no pretence at understanding the work of Marx. Joan Robinson's book on Marxian Economics prompted Keynes to admit 'I am left with the feeling, which I had before on less evidence, that he had a penetrating and original flair but was a very poor thinker indeed, - and his failure to publish the later volumes probably meant that he was not unaware of this himself (Letter from John Maynard Keynes to Joan Robinson, dated 20 August 1942, Joan Robinson Papers, King's College Archive Centre, L/42/102). Keynes took his ideas on monopoly from Marshall, where it was not properly integrated into the analysis of the economic system as whole. But it is possible that an influence similar to that Hilferding may have reached Keynes through the work of the founder of Institutionalist economics, Thorstein Veblen. Having distanced himself from Marx on account of the latter's 'teleological' claim to insight into the future evolution of capitalism, Veblen had found himself on a convergent path with Hilferding in the matter of long-term finance, and its associated monopoly capital. The American social critic criticised Marx for his 'romantic' Hegelianism (Veblen [1906] 1948) soon after the publication of Veblen's (1904) The Theory of Business Enterprise. In that book Veblen examined the financial economics of corporate (monopoly) capitalism and put forward one of the first analyses of the new credit cycle, based on changing values in the 
stock market, rather than on fluctuations in bank reserves. Keynes was sufficiently impressed to have the book on the reading list for his Cambridge lectures, and Veblen's influence is clearly visible in Keynes's famous account of stock market speculation in his General Theory (Lawlor 1994; Keynes 1936, ch. 12). ${ }^{3}$

Thereafter monopoly was consigned to microeconomics, and hence disconnected from finance or macroeconomic analysis. Keynesian and Post-Keynesian Economists (with the exception of those Sraffians like Geoffrey Harcourt, who consider themselves to be PostKeynesians) were quick to follow Keynes and distance themselves from the work of Marx. In the matter of finance, Post-Keynesians in general have preferred to follow Keynes, rather than follow Kalecki or Steindl to a financially-informed view of Marx and Hilferding. Notable exceptions here are Tracy Mott, who has taken up the question of firm size and the cost of finance, and the present author who has sought to uncover the role of corporate finance in macroeconomics (Mott 2009; Mott and Shapiro 2005; Toporowski 2000). Mention should be made here of the work of Hyman Minsky, who stands out among twentieth-century economists for his integration of corporate finance in macroeconomics. Indeed, Minsky's price theory, like that of Kalecki, was located in schemes of reproduction remarkably similar to those of Marx (Minsky 1986, ch. 7). However, in his understanding of finance, Minsky was inspired chiefly by Keynes. There is therefore no mention of Hilferding in his work, let alone Marx - Minsky experienced McCarthyism at a crucial early stage of his career. Moreover, his analysis of corporate finance is restricted to that of corporations, rather than

\footnotetext{
${ }^{3}$ Paradoxically, with the 1929 Crash, it was the social theory, rather than its analysis of long-term finance, that became the distinctive feature of institutionalism. Institutionalism never developed its insights regarding longterm finance into a proper macroeconomics that might have rivalled the more nuanced insights of Keynesianism and neo-classical economics (Sweezy 1958).
} 
taking in also unincorporated businesses, whose market interaction with corporations is the foundation of the business cycle theory derived from Hilferding.

Most twentieth-century Marxists contemporaries reacted otherwise to the challenge of finance and the monopolies it created. The response among Marxists to Keynes's ideas in economic theory and policy was to point out that Keynes did not adhere to the labour theory of value, even if he recognised a problem of insufficient demand in the economy. This was then the pretext for what I have elsewhere called "The Marxist Retrogression to Ricardian Socialism", that is a regression to the fundamental principles of the radical political economists who preceded Marx, espoused by writers such as John Gray (1799-1883) and Thomas Hodgskin (1787-1869). Those fundamental principles were the labour theory of value (from which the Ricardian Socialists derived their case for socialism as the right of labour to its produce) and underconsumption as the cause of poverty in capitalism, because workers were not paid the full value of their labour, and therefore cannot buy all that they are producing. While Marx had criticised the Ricardian Socialists for their moral critique of capitalism, and their inability to see how the system as a whole worked, he had shared their insistence on labour as the source of all value and recognised underconsumption as a symptom of capitalist depression (King 1983). The experience of the 1930s reinforced those elements in Marxist economic thinking. As Steindl was to observe of later developments in Marxism:

Marxism and radical economics, grown mainly from the ranks of the student movement since about 1968, have come to oppose the mainstream... this movement has not penetrated economics, rather it has established a ghetto. It has carved out a place for itself at the universities and has left the mainstream intact, and that mainly owing to the attitude of Marxists themselves, especially their lack of interest in current economic policy. The renaissance of Marx has concentrated not on emulation but on exegesis of his 
work. No doubt very much has been achieved here and we can be grateful for it. But Marx lived very much in his time and the Marxist economists do not seem to follow his example. (Steindl 1984, pp. 249-250)

That example, according to Steindl, was in any case ambiguous. Steindl had concluded his seminal work, Maturity and Stagnation in American Capitalism, with a chapter on 'Karl Marx and the Accumulation of Capital'. In this chapter he criticised the underconsumptionist interpretation of Marx that was laid down in Paul Sweezy's textbook of Marxian economics, The Theory of Capitalist Development (Sweezy 1942): 'In fact it [i.e., this interpretation] is nothing but a relic of that weird old monster, the wages fund doctrine which Marx killed in a brilliant attack, only to permit its ghost to muddle up his terminology! There is no reason nowadays, even for a Marxist, to preserve the remains of that fossil out of mere piety.' (Steindl 1952, p. 244). (Sweezy was to change his mind, and in 1976 generously published a second edition of Steindl's book, along with Steindl's original criticism of Sweezy. See Toporowski 2016. $)^{4}$

\section{Finance reborn as 'financialisation'}

The resort to underconsumption as the explanation of economic depression and stagnation by Marxists retrogressing to Ricardian socialism was merely a symptom of a much more fundamental rejection of any distinction between the classic capitalism that Marx described, and the finance capitalism that had emerged after the 1870s. The renewed insistence on examining latter-day capitalism using the categories of 'classic capitalism' coincided with the publication of collected writings of Marx and Engels in increasingly comprehensive editions,

\footnotetext{
${ }^{4}$ A similar path to a Ricardian analysis of 'classical' capitalism was trodden by the followers of Piero Sraffa, who represented Sraffa's classic work of logical analysis, The Production of Commodities by Means of Commodities as a model of an actual capitalism, as opposed to an exposition of a logical flaw in neo-classical analysis. The Sraffians differed from Ricardian Marxists in reinterpreting the labour theory of value as a usinfinance.
} 
have made it fashionable among Marxists to scan the works of Marx to find quotations or doctrines congenial to the outlook or the enthusiasms of the reader; or, if that reader is more scholarly, to find the 'true' meaning of particular doctrines. This gives rise to splendid and wordy rhetoric, but poor analysis. Sweezy's teacher Joseph Schumpeter had a point when he remarked that 'The cold metal of economic theory is, in Marx's pages immersed in such a wealth of steaming phrases as to acquire a temperature not naturally its own.' (Schumpeter 1987, p. 21). Such 'steaming' rhetoric focuses attention on doctrine and clichés rather than understanding. The insistence on particular verbal forms is probably the most common cause of sectarian division among Marxists, and between self-identified Marxists and those with more general interests, as well as papering over of problems in theory and practice. It is also a great discouragement to understanding the roots of much twentieth-century macroeconomic thinking in Marx's approach to the critique of political economy.

This is why many Marxists were caught unawares by the increasing prominence of finance in the early years of the twenty-first century, and why the theories of 'financialisation' that emerged from this Marxist analysis combine classic capitalism, characterised by bank borrowing (to which long-term finance is held to be equivalent) with underconsumption (linked to economic stagnation by many Post-Keynesians, through an inadequate 'wage share'). Theories of financialisation commonly have a Ricardian view of debt, in which debt is never an asset, as it is in a credit system, but a usurious claim on income.

Among the recent works on financialisation, those of Robert Boyer stand out for their systematic treatment of finance in a capitalist economy whose stability depends on the rate of capital accumulation, in the Keynesian sense of investment rather than saving. In the Regulationist analysis, this rate of accumulation is 'regulated' in different ways in different 
'regimes' of accumulation: Under the 'Fordist' regime, investment was maintained by mass production requiring machine technology. For Boyer, the question is whether deregulated finance can maintain adequate levels of accumulation to make capitalist stable. In his recent analysis, Boyer has argued that the financial crisis of 2008, and the subsequent economic stagnation can be attributed to the liberalised financial regime that took over from the Fordist regime. That financial crisis marks the end of 'finance-led growth', which Boyer had earlier identified in a more optimistic light (Boyer 2000). Finance has, in effect, has reached the end of its capacity to maintain growth. Echoing Bernanke's (2005) attribution of financial distortions in the US economy, Boyer (2013, p. 143) argues that the 'unbalanced US growth, built upon an excess of credit, was made possible by excess savings in Asia, especially China.'

The reliance of Boyer and other financialisation theorists on 'savings', whose excess, augmented by banks' credit-creation, is deemed to have caused economic stagnation and financial instability, establishes their critique of finance on a foundation of pre-Keynesian, pre-Hilferding, financial practices, in which debt drains income out of the system, as opposed to the modern practice in which the counterpart of debt is credit. The difference between the credit practices of 'classic capitalism', and the practices required by long-term financing, is fundamental: With long-term finance, debt is also an asset (credit) for another economic unit in the system; debt becomes a mechanism transferring income or bank deposits around the system, rather than draining income or bank deposits. (The reduction of bank deposits comes with the repayment of debt, rather than its transfer as a means of payment - see Kalecki 1943). This requires a deeper understanding of the financial circulation of money, and of interest as a redistributive mechanism, rather than a Ricardian rent, accounting for interest and financial payments as income, as well as expenditure. There is some evidence that this is 
indeed how Marx regarded interest, as a mechanism for redistributing income among capitalists, as opposed to pre-capitalist usury, draining capitalists' income for the benefit of non-productive classes (for example, in his discussion of interest-bearing capital in Capital Volume III, Marx 1974b, pp. 365-6, 508-512. See also Toporowski 2018).

Mainstream, neo-classical economics has failed to come to terms with long-term finance, and perceives capitalism as 'classic' capitalism, without the distinctive features of monopoly capital and finance capital, with which twentieth-century and twenty-first-century capitalism is imbued by markets in long-term finance. This is epitomised in the New Neo-Classical Consensus, in which the central bank (short-term) rate of interest serves as the regulator of economic activity and the price level, as it was supposed to do in the middle of the nineteenth century. That focus on the short-term rate of interest as a key policy instrument is paralleled by the slow abandonment of the long-term rate of interest by Post-Keynesian monetary economists.

\section{Conclusion}

Marx had noted the evolution in capitalist financing from short-term bank credit to long-term financing. However, he did not provide any account of how this changes the 'laws of motion' of the capitalist system. Long-term finance therefore poses a challenge to followers of Marx: To what extent is his account of those 'laws of motion' still valid for late-twentieth-century, or twenty-first century, capitalism? This leads to the more fundamental question of what is the lasting, as opposed to the ephemeral, legacy of Marx. In other words, what is the relevance of Marx today. Leaving aside the social and philosophical implications of his work, 
this paper argues that Marx's method of deconstructing market processes to reveal how the circulation of capital through industry and finance, creates and realises value, a method showing the 'laws of motion' of capitalism, remains the most valid part of his analysis.

That Marx's project was unfinished is common ground among all readers of Marx. That Marx's analysis was overtaken by the emergence of long-term finance, a financial innovation responding to the financing needs of large-scale capitalist enterprise, was recognized by Hilferding and his Austro-Marxist followers, Veblen, Keynes, Kalecki, Steindl and Sweezy. The failure to recognise the significance of this innovation has taken economics and political economy back to theorizing about a 'classic' capitalism that has not existed for over a century. The link between finance and capitalist enterprise is supposed to occur through the saving of 'classic' capitalists or rentier households, rather than through financial circulation. This focuses theoretical and policy attention on bank reserves as the key factor in the credit cycle. However, with long-term finance, it is the reserve position and credit policy of the business corporations created through the capital market, rather than the reserve position and credit policy of banks, that determines the future of any given conjuncture in the business cycle.

Symptomatic of this blindness towards financial circulation is the decline in the attention paid by modern economics to the long-term rate of interest, even among followers of the bestknown promoter of the significance of this rate of interest, John Maynard Keynes. There is more than one irony in this, since it was originally Karl Marx who originally hinted that it was the long-term rate of interest that may be a factor in capital accumulation (1974b, pp. 362, 366-8).

\section{Acknowledgement}


I am grateful to Lynne Chester, Steve Pressman and anonymous reviewers for helpful comments on an earlier draft. Sole responsibility for remaining errors lie with the author.

\section{References}

Bernanke, B. 2005. The Global Savings Glut and the U.S. Current Account Deficit. Homer Jones Lecture, April 15.

Boyer, R.A. 2000. 'Is a Finance-led Growth Regime a Viable Alternative to Fordism? A Preliminary Analysis.' Economy and Society 29: 111-145.

Boyer, R.A. 2013. 'The Present Crisis: A Trump for a Renewed Political Economy.' Review of Political Economy 25: 1-38.

Dellheim, J. 2018. "'Joint Stock Company" and "Share Capital” as Economic Categories of Critical Political Economy.' In Karl Marx's Unfinished System as a Challenge for Our Times: Reflections on Marx's Third Volume, edited by J. Dellheim and F.O. Wolf. London: Palgrave.

Dobb M.H. 1967. Papers on Capitalism, Development and Planning. London: Routledge and Kegan Paul.

Hilferding, R. [1920] 1981. Finance Capital. London: Routledge and Kegan Paul.

Hobson, J.M. (1932) 'Preface' to H.M. Hyndman, Commercial Crises of the Nineteenth Century. London: George Allen and Unwin, 1932.

Kalecki, M. [1932] 1990. 'The Influence of Cartelization on the Business Cycle.' In Collected Works of Michat Kalecki Volume I Capitalism Business Cycles and Full Employment, edited by J. Osiatyński. Oxford: Clarendon Press, pp. 56-59.

Kalecki, M. 1939. Essays in the Theory of Economic Fluctuations. London: George Allen and Unwin. 
Kalecki, M. 1943. 'The Short-Term and the Long-Term Rate of Interest.' in Studies in Economic Dynamics. London: George Allen and Unwin.

Keynes, J.M. [1930] 1971. A Treatise on Money: 1 The Pure Theory of Money. London: Macmillan.

Keynes, J.M. 1936. The General Theory of Employment, Interest and Money. London: Macmillan.

Kindleberger, C.P. 1993. A Financial History of Western Europe. New York: Oxford University Press.

King, J.E. 1983. 'Utopian or Scientific? A Reconsideration of the Ricardian Socialists.' History of Political Economy 15: 345-373.

Kowalik, T. [1971] 2014. Rosa Luxemburg Theory of Accumulation and Imperialism. Basingstoke: Palgrave.

Lawlor, M. 1994. 'On the Historical Origins of Keynes’s Financial Market Views.' In Higgling Transactors and their Markets in the History of Economics Annual Supplement to Volume 26, History of Political Economy, edited by N. De Marchi and Mary S. Morgan.

Durham NC and London: Duke University Press, pp. 184-225.

Lederer, E. 1925. 'Konjunktur und Krisen' in Grundriss der Sozialökonomik. Tubingen: JCB Mohr, pp. 354-413.

Lenin, V.I. [1915] 1969. Imperialism the Highest Stage of Capitalism. Moscow: Progress Publishers.

Marx, K. 1938. Capital: A Critical Analysis of Capitalist Production. London: George Allen and Unwin.

Marx, K. 1970. A Contribution to the Critique of Political Economy. New York: International Publishers. 
Marx, K. (1974a) Capital: A Critique of Political Economy, Volume II, The Process of Circulation of Capital. London: Lawrence and Wishart.

Marx, K. 1974b. Capital: A Critique of Political Economy, Volume III, The Process of Capitalist Production as a Whole. London: Lawrence and Wishart.

Marx, K. 1993. Grundrisse: Foundations of the Critique of Political Economy (Rough Draft). London: Penguin Books.

Minsky, H.P. 1986. Stabilizing an Unstable Economy. New Haven and London: Yale University Press.

Mott, T. 2009. Kalecki's Principle of Increasing Risk and Keynesian Economics. London and New York: Routledge.

Mott, T., and N. Shapiro. 2005. Rethinking Capitalist Development: Essays on the Economics of Josef Steindl Abingdon, U.K.: Routledge.

Niebyl, K.H. 1946. Studies in the Classical Theories of Money. New York: Columbia University Press.

Robinson, J.V. 1942. An Essay on Marxian Economics. London: Macmillan.

Schumpeter, J.A. 1987. Capitalism, Socialism and Democracy. London: Unwin Paperbacks.

Steindl, J. 1952. Maturity and Stagnation in American Capitalism. Oxford: Basil Blackwell.

Steindl, J. 1984. 'Reflections on the Present State of Economics.' Banca Nazionale del

Lavoro Quarterly Review No. 148: in J. Steindl, Economic Papers 1941-88 London: Macmillan.

Sweezy, P.M. 1942. The Theory of Capitalist Development Principles of Marxian Political Economy. New York: Oxford University Press.

Sweezy, P.M. 1958. 'Veblen on American Capitalism.' In Thorstein Veblen: A Critical Appraisal, edited by D. Dowd. Ithaca, NY: Cornell University Press. 
Toporowski, J. 2000. The End of Finance: The Theory of Capital Market Inflation, Financial Derivatives and Pension Fund Capitalism. London: Routledge.

Toporowski, J. 2016. 'Kalecki and Steindl in the Transition to Monopoly Capital.' Monthly Review 68: 39-48.

Toporowski, J. 2018. 'Marx's Critical Notes on the Classical Theory of Interest.' In Karl Marx's Unfinished System as a Challenge for Our Times: Reflections on Marx's Third Volume, edited by J. Dellheim and F.O. Wolf. London: Palgrave.

Tugan-Baranovsky, M.I. 1923. Pyeryodycheskye promyshlennye krizisy. Istoriya anglyskikh krizisov. Obshchaya teoria krizisov Smolensk: no publisher indicated.

Veblen, T. 1904. The Theory of Business Enterprise. New York: Charles Scribner's Sons. Veblen, T. [1906] 1948. 'The Socialist Economics of Karl Marx.' In The Portable Veblen, edited by M. Lerner. New York: Viking Press. 